\title{
The Power of Disturbance
}

\author{
Elsa Morante's Aracoeli \\ * \\ Edited by Manuele Gragnolati and Sara Fortuna
}

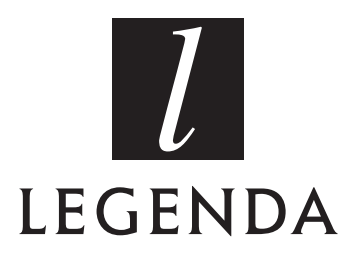

Modern Humanities Research Association and Maney Publishing 2009 
Published by the

Modern Humanities Research Association and Maney Publishing

1 Carlton House Terrace

London SW1Y $5 A F$

United Kingdom

LEGENDA is an imprint of the

Modern Humanities Research Association and Maney Publishing

Maney Publishing is the trading name of W. S. Maney $\mathcal{E}$ Son Ltd, whose registered office is at Suite 1C, Joseph's Well, Hanover Walk, Leeds LS3 1AB

ISBN 978-1-906540-50-0

First published 2009

All rights reserved. No part of this publication may be reproduced or disseminated or transmitted in any form or by any means, electronic, mechanical, photocopying, recording or otherwise, or stored in any retrieval system, or otherwise used in any manner whatsoever without the express permission of the copyright owner

(C) Modern Humanities Research Association and W. S. Maney E Son Ltd 2009

Printed in Great Britain

Cover: 875 Design

Copy-Editor: Nigel Hope 


\section{CONTENTS}

Acknowledgements

Notes on the Contributors

ix

I Introduction

SARA FORTUNA and MANUELE GRAGNOLATI

PART I: LANGUAGE AND (INTER-)SUBJECTIVITY

2 Between Affection and Discipline: Exploring Linguistic Tensions from Dante to Aracoeli

SARA FORTUNA and MANUELE GRAGNOLATI

3 Seeing and Telling: Anamorphosis, Relational Identity, and Other

Perspectival Perplexities in Aracoeli

20 REBECCA WEST

4 Resisting Paranoia: Poesis and Politics in Aracoeli FLORIAN MUSSGNUG

PART II: PSYCHOANALYSIS

5 'The Lover of a Hybrid': Memory and Fantasy in Aracoeli 42 CHRISTOPH F. E. HOLZHEY

6 Scene madri: Psychoanalytic Visions from Aracoeli to Volver 59 VITTORIO LINGIARDI

7 Baubo - Another and Additional Name of Aracoeli: Morante's Queer Feminism

ASTRID DEUBER-MANKOWSKY

INTERMEZZO

8 Staging the Passion of Aracoeli AGNESE GRIECO

PART III: ELSA E GLI ALTRI

9 Aracoeli and Gadda's La cognizione del dolore: Disturbed Sons, Disturbing Mothers GIUSEPPE STELLARDI

IO Politics and Sexuality in Pasolini's Petrolio FRANCESCA CADEL

I I Between Italy and Spain: The Tragedy of History and the Salvific Power of Love in Elsa Morante and María Zambrano ELISA MARTÍNEZ GARRIDO 
viii Contents

PART IV: RELIGION

I2 The Womb of Dreams: Cabbalistic Themes and Images in Elsa Morante's Aracoeli SERGIO PARUSSA

I3 Morante and Weil: The Aporiae of History and the End of the Fairy Tale CLAUDE CAZALÉ BÉRARD

I4 Indian Traces: Aracoeli, Pasolini's L'odore dell'India, and Moravia's Un'idea dell'India

MIMMA CONGEDO

Bibliography

Index 


\section{PART III \\ $\nLeftarrow$ \\ Elsa e gli altri}




\title{
CHAPTER 9
}

\section{Aracoeli and Gadda's La cognizione del dolore: Disturbed Sons, Disturbing Mothers}

\author{
Giuseppe Stellardi
}

Why mention Gadda in relation to Elsa Morante? What can Aracoeli and La cognizione del dolore possibly have in common?

The external chronology and the socio-historical context of the two works, for one thing, set them apart: Morante's last novel was published in 1982, whereas Gadda's first one appeared initially in instalments between I938 and I94I. ${ }^{\text {I }}$ A fortyyear gap (with a world war and the end of a dictatorship in between) may not be a decisive factor in itself, but it certainly signals at the very least a significant historical divide, suggesting the likelihood of an accompanying, profound mutation of perspectives (political, literary, or other).

More significant is the stylistic difference. Whereas Gadda, with the baroque polyphony and '(pre-)postmodern"2 parodic folds characteristic of his language, is seen as a daring literary innovator, Morante seems to embrace a more traditional approach to narrative writing. ${ }^{3}$ Also, La cognizione is narrated in the past and in the third person by an extra-diegetic, anonymous, omniscient narrator, whereas Aracoeli is a long monologue in the present time (with extensive flashbacks) by the protagonist, Manuele.

Furthermore, the setting is fictional in Gadda (an imaginary South American country, closely resembling the author's native Brianza, in a time that - without explicit mention of it - seems to correspond to the 'ventennio'), mostly real in Morante (Rome, Milan, Spain, over a time-span ranging from the Italian Fascist era to the death of the Spanish dictator, Francisco Franco). However, if the setting is openly imaginary in Gadda and essentially realistic in Morante, the effect of both characterization and narrative setup is such that La cognizione sounds scrupulously truthful, whereas Aracoeli — projecting on the page the probably distorted subjective vision of its narrator-protagonist - emanates an aura of uncertainty. For this aspect at least, the novel belongs to the literary model whose archetypes (within the Italian twentieth-century tradition) can be found in Svevo's La coscienza di Zeno, or the Pirandello of Uno, nessuno e centomila. The 'unreliable narrator' is a crucial component of this literary model and Manuele, with his tendency to dwell in the past and uncommon disposition to dream, re-proposes the mind-structure of a Zeno Cosini. ${ }^{4}$ 
Ultimately, the two novels 'feel' different when we read them. Despite this, however, a strong, obvious parallel unites them: they both tell the story of a single male character, whose life and destiny seem to have been profoundly and permanently affected by events taking place during infancy and childhood, and in particular by the influence of a powerful and (in very different ways) disturbing maternal figure.

Let's take a look at the two protagonists. They show at first sight considerable differences, particularly in social standing and psychological characterization: whereas Manuele is almost an outcast, very close to the margins of society by virtue of his ill-defined professional position, lack of significant social relations, weak character and degrading sexual habits, Gonzalo leads an unimpeachable life of bourgeois respectability and apparent fulfilment, surrounded in his villa by the fearful deference of servants and peasants, as well as of his old mother.

Nevertheless, there are striking, if superficial similarities. For instance, the age of the two protagonists: Manuele is forty-three years old at the time of his journey to Spain, almost exactly Gadda's age when (following his mother's death in 1936) he started writing La cognizione. Considering that the novel's hero is most certainly an autobiographical projection, we can safely assume that forty-three is, approximately, Gonzalo's age, too. But age is not the only thing they have in common. Their background is similar: both are the offspring of respectable bourgeois families. And similar also is their state of secret malaise: Gonzalo, too - like Manuele — is undergoing a profound personal crisis that has no obvious causes or possible cure, and which Gadda's narrating voice felicitously names 'il male oscuro':

di cui le storie e le leggi e le universe discipline delle gran cattedre persistono a dover ignorare la causa, i modi: e lo si porta dentro di sé per tutto il fulgurato scoscendere d'una vita, più greve ogni giorno, immedicato. (La cognizione, p. 690$)^{5}$

So, Gonzalo and Manuele are two clear examples of male, middle-aged, bourgeois disadaptation, of that syndrome of discontent that finds its origin in the passionate, youthful, pre-romantic, suicidal heroes of Goethe and Foscolo, and then - through subtle transformations, and primarily relentless extenuation - turns itself into the literary expression of the curse of modern society: the inexplicable unhappiness of contemporary man. Love is at the root of Werther/Ortis's as well as Gonzalo/ Manuele's fate. But a complete reversal has taken place in the course of this process: whereas Werther and Ortis, young and full of life, nobly commit suicide out of unrequited love, our two heroes' sufferings, albeit still related to the central issue of love (as we shall see), have become altogether less heroic, noble, or even simply understandable. Precisely for that reason, they come to symbolize the dark side of the triumphant modern world. They are the incomprehensible side-effect of the incessant progress of civilization. But is it merely a negligible sub-product, or the symptom of a fatal and universal fault, the secret time-bomb that will in the end annihilate the entire species? ${ }^{6}$

Be it as it may, introspective self-centredness is one of the symptoms of this elusive illness. Manuele and Gonzalo show a similar detachment from their surrounding environment, and in particular a lack of engagement with the political issues of the 
time, and more generally a lack of participation in collective dynamics - beyond of course what is unavoidable. Their desperate solitude is quite poignantly described, in terms most of the time devoid of any attempt at ennobling heroicization.

Not only do Gonzalo and Manuele have a problem in common, they also both seem to trace it back to the very early stages of their life, and more precisely to the figure of the mother. Each mother is seen as crucially connected with (if not responsible for) the son's misery. But, here again, a significant divergence manifests itself.

In La cognizione, the mother is mentioned only as la signora, or la madre, or la mamma. She unmistakably corresponds, to a large extent, to the real-life person of Adele Lehr, Gadda's own mother. La signora is described as an elderly, sweet lady, sharing with a son on the verge of middle age a simple but dignified existence in her villa in the countryside, making friends with peasants, doing good deeds, and preserving the memory of her husband and of her (other) son, both long dead. But, in the same way as the apparently idyllic life he leads is in fact an intolerable hell to Gonzalo, so too does the superficially saintly image of the mother hide an altogether more disturbing truth (for him, at least). She is indeed remembered by Gonzalo, in her previous and now remote incarnation as a young mother, as 'una belva': a sadistic educator, who eagerly introjected and ruthlessly implemented all dogmas of bourgeois education and behaviour. The protagonist's recollection of his childhood is that of a painful and senseless mortification at the hands of his educators: his teachers, his father, but primarily his mother, to whom he ascribes in large part the responsibility for his 'illness'?

The opposite applies to Manuele. He remembers his infancy and early childhood as a time of bliss, marked by a state of total fusion with the person of his loving mother, young and beautiful Aracoeli. This exclusive, self-contained, and perfectly fulfilling relationship is progressively affected and ultimately destroyed by a sequence of events, narrated by Manuele in long flashbacks interspersed into the present-time narrative: the removal of the mother-son dyad from 'Totetaco' (the secluded, secret haven in the Montemario quarter of Rome where the two are initially confined by bourgeois conventions) to the apartment in the Quartieri Alti, where their induction into respectable society can take place; the second pregnancy of Aracoeli, leading to the birth of a little sister, who will die almost immediately; the tragic descent of Aracoeli into madness and nymphomania, accompanied by her incomprehensible (for him) rejection of her son, Manuele; and finally her departure and, later, her death.

The two mothers are antithetic, and this is evident even in their ethnic and geographic provenance. Adele Lehr (Gadda's real mother, truthfully portrayed under the guise of Gonzalo's mother) was of Germanic origins, and inclinations. ${ }^{8}$ A teacher by profession, she was well-educated and perfectly at ease in polite society. Aracoeli is Spanish by nationality, and Mediterranean in temperament; thoroughly uneducated and blissfully ignorant, she has considerable difficulties in learning Italian, as well as in obeying (and, first of all, understanding) the dictates of bourgeois behaviour.

The difference between the two mothers is dramatically accentuated when it comes to their relationship with their respective sons, and in particular to their pedagogical demeanour: if Aracoeli is ultimately unable (also in her educational 
methods) to abide by the rules of middle-class decorum, and at first swamps Manuele in unbounded maternal love (only to subject him subsequently to a traumatic rejection), la signora instead seems to have internalized the strictest demands of the paternal-symbolic order and, in the pursuit of an almost inhuman pedagogical ideal, deprives young Gonzalo of any sign of real affection. As a result, in the early part of his life Manuele is drowned in love, whereas Gonzalo is starved of it.

But, once again, it might be said that the effect on the two men is structurally similar: an emotional imbalance in the mother-son relationship in the early years leads to disastrous consequences later on, and essentially to an inability to live a 'normal' relational life. It is important to pay attention, however, to significant differences in those 'consequences', particularly at the level of the psychological makeup of the characters; if Manuele's behaviour seems essentially marked by masochistic traits (highlighted especially in his often degrading relationships with his male lovers), in Gonzalo's case there are obvious sadistic connotations (emerging in daydreams hinging on the extermination of unwelcome visitors, or in moments of uncontrollable rage, ${ }^{9}$ resulting in outrageous rants, or the destruction of symbolically significant objects, such as his father's portrait, or a watch received in gift from his mother).

A further point worth mentioning, if only en passant, concerns the marginality of both fathers: one, Gonzalo's, is long dead, nor does he seem to hold or to have held a very important place in his heart (whereas the memory of his brother, killed in war, is both sacred and painful, being connected with a bundle of inextricable sentiments, including remorse and jealousy); the other, Manuele's father, during the child's early years is most of the time absent on duties connected with his position in the Italian navy, and in his brief visits much more interested in Aracoeli than in his son, who in exchange feels for him no more than distant respect. This respect turns later to disgust when, after the end of the war, Manuele visits him (now, after Aracoeli's death, no more than a human wreck); until, in the end, Manuele undergoes the sudden revelation of a different sentiment for him (more on this later).

Returning to the sons, I would like to suggest that the main dissimilarity between Manuele and Gonzalo (who, as we have seen, both embody the same, unhappy aspect of the human condition in the modern world) concerns their respective relationships to love. Both suffer from a form of mutilation, with longlasting consequences; but if for Manuele the syndrome is that of a loss of love, in Gonzalo's case it is more appropriate to talk of an originary lack of love. What might seem at first sight a subtle distinction reveals itself instead as a crucial difference.

Manuele's curse is that (as he knows full well) he will never be loved again in the boundless, unrestrained manner Aracoeli loved him in the first years of his life. ${ }^{\text {IO }}$ The loss of love (after extreme overabundance of it) is naturally a very heavy burden to bear.

Gonzalo's fate, however, is even worse: he's never been loved in the first place, he never had (or at any rate can't remember having, but it amounts to the same thing) the gratuitous and immeasurable affection of a loving mother. ${ }^{\text {II }}$ As a result of this primary lack of love, Gonzalo's syndrome is more complex, and his case receives an altogether darker complexion, as we shall see. 
The whole problem affecting our two heroes, therefore, revolves around what I should like to describe as the remembrance of love: although in both cases the diagnosis is one of insufficient love, Manuele distinctly remembers being loved, and this recollection is the fulcrum of his life; Gonzalo doesn't, and for him, too, this is the central truth of his existence. What follows is the inevitable consequence of this simple but momentous premise.

Aracoeli is the story of Manuele's attempt to return to his mother, to find her again, and - with her - the immensity of the love he remembers having bound the two of them. It doesn't matter that for a time he had rejected and even forgotten about Aracoeli; in the end he abandons whatever little he has (home, job, relations), the minuscule securities of his senseless life, to set his course again towards his sole true star. He then embarks on a private odyssey, which geographically and spiritually takes him back to Aracoeli in the disembodied shape in which, alone, she can now be found, at the topographical locus of her origins.

Gonzalo has nowhere to return to. In his vain attempts to get to the root of his problems, he comes to identify his mother (who, as already mentioned, has no name in the book: compare this to the place Aracoeli, and her name, occupy in Morante's novel, and in Manuele's language) as the ultimate source of his unhappiness, so that the physical attack perpetrated (probably by thieves) against her in the final chapter has the unmistakable signs of a materialization of the son's (more or less unconscious) matricidal desires.

It is interesting that neither Manuele nor Gonzalo (unlike their distant ancestors, young Werther and Jacopo Ortis) wish to take leave of their own unhappy existence; they expect (obscurely, and mistakenly) to recover the fullness of their life, one by re-conjoining himself with Aracoeli, the other (semi-consciously) by ridding himself once and for all of his mother. Neither can succeed: summoning a ghost from the depths of the past cannot possibly result in the reconstitution of a relationship that was bodily and physical as much as spiritual; on the other hand, the 'killing' of the mother will only add further bleakness to Gonzalo's existence. ${ }^{\text {I2 }}$

Before going any further, I shall at this point introduce a consideration that may seem far removed from the matter at hand, and from the ideological makeup of both works, and authors. It has to do with the definition of Christianity; there are of course many possible definitions, but there is one that has (as shall be seen) a direct relevance to the present discussion. It goes like this: Christianity is the remembrance of the love of God. That's all. In its simplicity, this is a truly enlightening phrase. ${ }^{\mathrm{I}}$ I take it as meaning that the joy and hope of Christian life (for those who believe in the Christian message, of course) does not have its origin and justification within the human being, in anything that one does or doesn't, but in God, and cannot therefore be affected by anything that happens to the human being. It also means that, no matter what depth of depravation and dejection one should fall into, the certainty of having been loved once, to the extent of having been brought into life, for no reason other than love, should always remain as the North Star of salvation for all men. The undivided and unconditional love of God, that preceded and exceeds all sins, loss, and despair, is what gave life to the entire 
universe and to all human beings, of course, not just Christians. But the Christian is the one who preserves the recollection of the love of God, and draws from it the very meaning of his life, as well as the ability to love not only God, but also others, in return for the love gratuitously received. ${ }^{14}$

Now, am I suggesting that Morante and Gadda are Christian writers? Before replying too hastily with a resounding no, we should at least mention the Christological qualities and air of holiness pertaining to the little Usé, the co-protagonist of Morante's La Storia. And we should also remember that the title of La cognizione del dolore was translated into English as Acquainted with Grief, again with an obvious biblical and evangelical reference. ${ }^{\text {Is }}$

However, I readily concede that it would be difficult to find in either Aracoeli or La cognizione del dolore any specific evidence of religious belief on the part of the two protagonists, and I am not in the least attempting to demonstrate that Elsa Morante and Carlo Emilio Gadda are Christians. But the metaphorical possibilities offered by this truly unlikely interpretative angle are quite illuminating and deserve to be pursued.

Ultimately, at least by virtue of the definition provided above, the answer to the question must be no for Gadda, given the absence in his work (and certainly in Gonzalo) of that essential Christian quality that is charity, or love; for Morante the surprising answer could be yes, provided one doesn't think of Christianity as a church, that is, a social institution, or a codified set of rites and rules, but rather as a manifestation of the fundamental disposition of the human being to remember love, and to love in return.

But let us return now to earth. Within the immanent, non-religious dimension, only one human experience resembles (in the collective imaginary) the relationship that Christians, according to the definition given above, believe to exist between their creator and themselves; it is, of course, that of maternity. A mother, in giving birth, replicates the act of creation, and her love for her child is comparable to that of God for his creatures, in that it is truly gratuitous and uncalculating. It is also absolute and unconditional, in that it doesn't depend on any requirements being fulfilled, other than the existence of her child. (I should stress that I am far from implying that this is a correct, factual, and universally true interpretation of the phenomenon of maternal love; it is, instead, a cultural stereotype that happens to chime with one of the fundamental attributes of the Christian God. I add that it is by no means necessary to assume that maternal, 'Aracoelian' love is a diminished copy of divine love: we are free to believe instead that Christian love, and the entire edifice of Christianity, is but a projection and amplification of a common idealization of maternal love. None of this affects the powerful metaphorical impact of those ideas.)

It is no surprise, therefore, that Aracoeli for Manuele is God. Blocked in his emotional and ideological development by the trauma of his mother's illness, rejection, and death, and prevented at some level from accessing the symbolic realm, he hasn't truly moved on, and still re-enacts (or at least seeks), especially in his sexual relationships, the total, adoring dependency that was his normal and satisfying state of being in the presence of Aracoeli. Now that she is gone, Manuele 
tries to establish with her a link, a bind that can only be described as religious: Aracoeli occupies the space of the divine in her son's life.

This resolves, among other things, what I perceive as a little riddle, which doesn't seem to have a proper solution in the text itself. Why does Manuele not accept a perfectly plausible medical, positivistic explanation of his mother's illness? ${ }^{\mathrm{I}}$ It may be that, in his resentment at having been so unjustly rejected by his mother, he doesn't want to let her off so easily. Also, he promptly detects aunt Monda's ulterior motives ('Certo, il suo era un pretesto inventato per salvaguardare l'onore della famiglia' (Aracoeli, p. I44I)), and so is inevitably suspicious of the 'logical' explanation that, at the same time as having scientific validity, also saves the family's face. But the primary reason for his refusal may be another one: perhaps he rejects the 'charitable' explanation because it diminishes Aracoeli's divinity. The divine is not questionable. Manuele can hate Aracoeli, can even try to forget her for a time, but he can't accept seeing her lowered to the station of a common mortal. Also, as a divine being she needs no justification, nor does she need to explain her own behaviour; no matter how hurtful, incomprehensible, and unacceptable her conduct towards Manuele is, it is still better for him to take it as the expression of an impenetrable, superior will, rather than the manifestation of human illness and decay.

Gonzalo's world is truly devoid of any God, and of any love. With no recollection of ever having been loved by a God, or by a mother, the hidalgo ${ }^{17}$ is condemned to a loveless life. Any attempt to penetrate his carapace of suspicion and cynicism is systematically rebuked by him. ${ }^{\text {I8 }}$ Lacking the experience (or the memory) of the only form of love that triggers the ability to love, he not only is unlovable, but also - which is much worse - is fundamentally incapable of love. I should stress again that what truly matters is that he doesn't remember having been loved in that (or any other) way. The lack of boundless maternal love - a truly disastrous mutilation for a human being - could perhaps be compensated, if Gonzalo could believe in God: but he clearly can't.

By contrast, having been loved in that boundless manner, and remembering it all too well, Manuele will forever suffer withdrawal symptoms, but at the same time is forever enabled to love back (in his own pathetic and unsatisfactory way), even knowing that he will never be loved again. The last sentence of Aracoeli is emblematic: 'ma certi individui sono più inclini a piangere d'amore, che di morte' (p. I454). In a communal destiny of loss, love is Manuele's saving grace.

The basic definition of the two characters can also be connected with this fundamental configuration. Gonzalo's only possible relationship to the divine/ maternal is violence, rage, and blasphemy. ${ }^{19}$ Manuele's disposition towards the only manifestation of the divine he knows and loves, Aracoeli, is prayer; which again shows the profoundly religious nature of his relationship to her.

The attribute of the divine, be it the Christian God or its parallel, Aracoeli, is a power of salvation. The circulation of love set in motion at the moment of creation/ birth is not easily stopped, although of course it is within the possibilities of human free will to do so. This is why Manuele is and remains capable of love.

Manuele's ability to love, and its full significance, is revealed (albeit somewhat enigmatically) at the end of the novel, when he suddenly discovers that the acute 
emotion he had felt after his last encounter with his father (by then the pathetic and utterly unlovable figure of a chronic alcoholic) was nothing other than love. The (unjustified and illogical) love of his father is the seal of Aracoeli's final gift: Manuele will not be loved again, but he will forever be able to love. Such is the (secretly) salvific sense of Morante's last and bleakest book.

Gonzalo's destiny is only superficially similar, but is in fact much darker. Disconnected from a primordial source of unqualified love, his world is as poisoned and rotten as that of Hamlet, prince of Denmark. ${ }^{20}$ Like Hamlet, he is condemned to a spasmodic pursuit of truth against all false pretences of society and family, but in so doing he can only resort do destruction and, ultimately, is doomed to self-destruction. This is what the insistent Gaddian leitmotiv of matricide suggests: the aggression against the mother is the equivalent of the revolt against God and his creation. Although it may be conducted in the name of justice and truth, it is the gesture of Satan, it denies life itself, and cannot possibly lead to salvation. The crusade against mendacious appearances, ultimately, does not justify the assault against life itself: nothing does.

And this does not simply pertain to the realm of literary fiction; for Gadda, too, literature is the battlefield of truth and justice:

Nella mia vita di 'umiliato e offeso' la narrazione mi è apparsa, talvolta, lo strumento che mi avrebbe consentito di ristabilire la 'mia' verità, il 'mio' modo di vedere, cioè: lo strumento della rivendicazione contro gli oltraggi del destino e de' suoi umani proietti: lo strumento, in assoluto, del riscatto e della vendetta. ${ }^{2 \mathrm{I}}$

But the war is lost in advance.

Manuele doesn't pursue truth, he doesn't have to. He simply follows Aracoeli, and this is an enterprise of love, because love is a bond with a person, not the subservience to a concept; and in the end he finds her again (albeit in a hallucinatory fashion). To her he confesses his sins:

Dovunque, ho peccato. Nelle intenzioni e nei fini e negli atti ma peggio di tutto nell'intelligenza. L'intelligenza si dà per capire. E a me si è data, ma io non capisco niente. E non ho mai capito e non capirò mai niente. (Aracoeli, p. I428)

But Aracoeli absolves him, at the same time revealing the ultimate truth: 'Ma, niño mio chiquito, non c'è niente da capire'. Manuele can be spared Gonzalo's pointless and loveless search for justice and truth, and will be saved through love.

There is therefore a positive conclusion to Aracoeli: positive, but not propositive, in that it doesn't entail a project, a concept, an analysis, or a solution, even less a plan or a strategy. It simply states the pointless immortality of love, which never has its reason in something (the specific reasons and needs of a specific subject), but rather in (the love received from or given to) someone else. Love is then an infinite transfer of force, an infinite postponement of hope, through which salvation, if not achieved, can at least infinitely be deferred, and expected.

All of this is also reflected at the level of stylistic and linguistic differences between the two novels. In Gadda we witness a perennial tension, seldom resolved in some state of equilibrium; this condition has been abundantly described by critics 
(and sometimes by Gadda himself) as the baroque quality of his language, constantly propelling it, through alternating centrifugal and centripetal forces, beyond stasis or balance, beyond itself. It is also, possibly, what prevents Gadda from resolving any of his major works into some sort of satisfyingly linear conclusion. His writing shifts between stylistic extremes (from lyrical verticality to paratactical accumulation, from pathos to bathos, from philosophical sequentiality to irrational associations), in an ongoing and incurable spasm of both the mind and the heart.

Morante's novel, instead, despite the bleakness of the story and of Manuele's prospects in life, conveys some sort of stoical serenity. True, Manuele doesn't have much to look forward to in his future, but his universe, albeit in turmoil, is firmly rooted, and so is his language, and so is Morante's novel. The work is solidly organized and properly (if enigmatically) concluded. Gadda's protagonist, instead, despite (or perhaps precisely because of) his obsessive search for truth, is ultimately and fatally disorientated, and so is the narrative that conveys Gonzalo's tale.

It is significant that both novels can be seen as being organized around forms of travel. Manuele moves in space towards his mother's origins, in time towards his own past, and in spirit towards Aracoeli; and - with the proviso that neither he nor we can be certain of the veracity of what we are told - all these movements reach their goal. So, both he and the novel he inhabits contradict the bleakness of his life, of its content, by charting a meaningful universe. In La cognizione we (the reader) move progressively towards Gonzalo, through the tales of the villagers and then the doctor's visit to his patient, in his villa, on his bed; but we don't reach him, never getting to the bottom of his truth. Gonzalo himself is in a state of constant but disordered, impatient motion, never happy where he is, always picking up his small suitcase, to go to work, certainly, but also to escape from his village, his villa, his mother, himself. His universe (and that of the novel) is chaotic; nothing in it makes sense or has a real direction.

In conclusion, Gadda and Morante are perhaps the two Italian authors who, after Dante, have approached the theme of love in the most striking way; both have steered clear of romantic stereotypes and attempted to recover, in their own respective literary worlds, a more primordial dimension of the most fundamental binding force in human experience. In doing so, they have struck an original, sincere, and profoundly touching chord that sets them apart from most contemporary writers.

Although both novels deal with the same problem, they ultimately point in opposite directions: if Gonzalo, in his Hamletic pursuit of truth and justice, seems destined to a nihilistic rejection of life (symbolized by the mother) and ultimately to self-destruction, Manuele's indelible memories of Aracoeli's boundless love seem to provide a path to some sort of salvation, providing him with an incomprehensible but indestructible potential for human empathy.

I have briefly shown that the divide separating Gonzalo from Manuele is also reflected structurally, linguistically, and stylistically: whereas La cognizione constantly and in all sorts of ways oscillates between implosion and explosion (silence and logorrhoea, lyricism and the baroque), Aracoeli is clearly dominated by an anamnestic (in both the philosophical and medical meaning), linear-circular, 
and almost Dantesque orientation, 'saving' the text from the destiny of internal incompleteness and infinite displacement that affects most of Gadda's narrative writing. Certainly, Manuele's last encounter with Aracoeli is not the same as Dante's vision of God; but, in a world, like that of Morante, without God, this is perhaps as far as man can go in the direction of the divine.

\section{Notes to Chapter 9}

I. Then complete in I963, with a second, augmented edition in 1970. Carlo Emilio Gadda, La cognizione del dolore, in Romanzi e racconti, ed. by Raffaella Rodondi, Guido Lucchini, and Emilio Manzotti, 2 vols (Milan: Garzanti, I990), I, 571-772; Elsa Morante, Aracoeli, ist edn (Turin: Einaudi, I982), quoted from Opere, ed. by Carlo Cecchi and Cesare Garboli, 2 vols (Milan: Mondadori, I988-90), II (I990), pp. I039-I454. Further references to these editions will be given after quotations in the text.

2. There is considerable debate concerning the classification of this author in terms of the modern/ postmodern distinction. I have contributed to it in 'L'alba della Cognizione: Gadda postmoderno?', in Disharmony Established: Festschrift for Gian Carlo Roscioni, Proceedings of the first EJGS international conference, Edinburgh, IO-I I April 2003, ed. by Emilio Manzotti and Federica G. Pedriali, Electronic Journal of Gadda Studies [henceforward EJGS], 4.3 (2004) <http://www.arts. ed.ac.uk/italian/gadda/Pages/journal/supp3attiI/articles/stellaconfI/articles/stellaconfI.php > [accessed I4 September 2008]). Now revised in Giuseppe Stellardi, Gadda: miseria e grandezza della letteratura (Florence: Franco Cesati, 2006).

3. This does not exclude the validity of an entirely different critical approach to the two authors: in Gadda it is possible to identify a profound streak of conservatism (not only in politics, but also in his literary allegiances), whilst in Morante's work one can readily perceive traits of great originality, as some other contributions in this same volume show.

4. Manuele is aware of the unreliability of his own 'testimony'; see for instance the imaginary dialogue between l'Accusa and l'Imputato: 'A. "[. . . [ Ritiene, in definitiva, il Soggetto, che le sue memorie siano ATTENDIBILI?" | I.: "Purtroppo, io non lo so"' (Aracoeli, p. II 86).

5. 'Il male oscuro' will later become the title not only of a successful novel by Giuseppe Berto (I964, turned into a movie in I990), but also of a famous song by Lelio Luttazzi ('il male oscuro, il male oscuro, quello che fa picchiar la testa contro il muro'), showing how Gadda's phrase struck a durable chord in the collective imaginary of Italian society.

6. We are reminded, once more, of La coscienza di Zeno, and precisely of its last page, evoking (with its 'prophecy' of a final explosion) exactly this catastrophic scenario.

7. There are also other causes for his unhappiness; the traumas related to the war and to the death of his brother are specifically mentioned. It goes without saying that the causal system so identified never achieves the status of a positive, scientific explanation: it remains confined to the role of a subjective and perhaps arbitrary reconstruction. The anonymous narrating voice, however, does not dismiss the 'reality' of Gonzalo's ailments, inviting the reader to 'consider everything', and suggesting the existence of remote origins, directly linked to the mother, for his condition:

'Ma tutto, tutto, è bene che si soppesi. Il figlio pareva aver dimenticato al di là d'ogni immagine lo strazio di quegli anni, la incenerita giovinezza. Il suo rancore veniva da una lontananza più tetra, come se fra lui e la mamma ci fosse qualcosa di irreparabile, di più atroce d'ogni guerra: e d'ogni spaventosa morte.' (La cognizione, p. 69r)

And later on, following the exposition of one of Gonzalo's moment of 'madness': 'Ma nulla accade senza ragione. Un mero arbitrio della iniquità è a stento pensabile in un animo non crudele'; and the narrator hypothezises 'che vi fosse una ragione o una causa, o più ragioni o più cause, forse, ignote agli umani, irreparabili, perché l'animo dello hidalgo andasse così privo di ogni gioia' (La cognizione, p. 7I2).

8. Gonzalo himself is described as germanico, and this trait is connected explicitly to his mother's blood: 
'Per parte materna [. . .] veniva di sangue barbaro, germanico e unno, oltreché langobardo; [. . .]. Germanico era in certe maníe d'ordine e di silenzio, e nell'odio della carta unta, dei gusci d'ovo, e dell'indugiare sulla porta coi convenevoli. In certo rovello interno a voler risalire il deflusso delle significazioni e delle cause, in certo disdegno della superficievernice, in certa lentezza e opacità del giudizio [. . .]. Germanica, soprattutto, certa pedanteria piú tenace del verme solitario, e per lui disastrosa, tanto dal barbiere che dallo stampatore.' (La cognizione, p. 606)

9. 'Impotente rabbia era in lui, nel figlio: dàtole un pretesto, subito si liberava in parole, tumultuando, vane e turpi: in efferate minacce. Come urlo di demente dal fondo di un carcere' (La cognizione, p. 688).

Io. 'MAI PIÚ TU SARAI | UN OGGETTO D'AMORE | MAI PER NESSUNO MAI | MAI TU SARAI UN OGGETTO | D'AMORE' (Aracoeli, p. IO94).

II. In Gonzalo's mind, it isn't necessarily the case that la signora was utterly incapable of maternal love; what makes things even more painful for him is that he believes she loved her other son (his dead brother) a lot more than him, whom for some mysterious reason she saw as 'defective': 'la prova difettiva di natura' (La cognizione, p. 678).

I2. Gonzalo, of course, doesn't kill his mother, but the theme of matricide is obsessively present from the early phases of Gadda's literary career, and the threat itself is clearly uttered by Gonzalo in a moment of desperate rage: 'Se ti trovo ancora nel braco dei maiali, scannerò te e loro' ( $L a$ cognizione, p. 737). But he also knows that the removal of the mother will not heal his wounds: see the dialogue with the doctor, during which Gonzalo recounts his obscure dream-premonition of the death of the mother, leading to his own complete freedom, but also to further misery, 'nella casa vuotata delle anime' (La cognizione, p. 633).

I3. The current pontiff, Pope Benedict XVI, has insisted repeatedly on this theme. As the then Cardinal Joseph Ratzinger, he wrote: 'Christianity is this remembrance of the look of love that the Lord directs to man, this look that preserves the fullness of his truth and the ultimate guarantee of his dignity' (Christianity and the Crisis of Cultures (San Francisco: Ignatius Press, 2006), p. 7I).

I4. Which means that our ability to love will never be as full as that of God, who loved us unconditionally, and not in return for love already received.

I5. 'He was despised and rejected by men; a man of sorrows, and acquainted with grief' (Isaiah 53. 3; The New Oxford Annotated Bible (Oxford: Oxford University Press, I973)).

I6. Such a justification of Aracoeli's intolerable behaviour is charitably offered by aunt Monda: 'Adesso che sei grande', proferí, 'tu devi saperlo. La tua mamma si è sempre comportata da Signora! da vera Signora! E quella sua condotta. . . strana degli ultimi tempi era un sintomo. . . una conseguenza della sua malattia. Sono effetti che si verificano, in certi casi. Me l'ha spiegato un Professore: uno specialista esimio!' (Aracoeli, p. I44I) But Manuele doesn't accept the explanation: 'Io mi scontorsi sulla sedia. Non ho creduto a questa nuova storia della vecchia Raimonda' (Aracoeli, p. I44I).

I7. One of the aliases used to refer to Gonzalo in the novel; others are il marchese, or simply il figlio.

I8. We see such advances attempted (clumsily) by the Doctor, and (fearfully) by the mother herself. But nothing can get through Gonzalo's disdain for what he considers vain and deceitful appearances ('bugie meritorie, grasse', La cognizione, p. 632).

19. See my 'La violenza in Gadda', EJGS, 6 (2007) <www.arts.ed.ac.uk/italian/gadda/Pages/ journal/issue6/articles/stellarviolo6.php> [accessed I4 September 2008].

20. 'Something is rotten in the state of Denmark'. For a summary of the significance of Hamlet's figure for Gadda, and the presence of a fundamental Hamletic structure in La cognizione del dolore, see my 'Amleto', EJGS, 3.I (2008) <http://www.arts.ed.ac.uk/italian/gadda/Pages/ resources/walks/pge/amletostellardi.php> [accessed I4 September 2008].

2. Carlo Emilio Gadda, 'Intervista al microfono', in I viaggi la morte, in Saggi giornali favole e altri scritti, ed. by Liliana Orlando, Clelia Martignoni, and Dante Isella, 2 vols (Milan: Garzanti, I99I), I, 503. 